Jurnal Politico Vol. 2 September 2018

Halaman 264-275. ISSN: p; 1829-6696, e:2549-4716

Web jurnal online; jurnal.unmuhjember.ac.id

Putri Robiatul Adawiyah

INOVASI DALAM PELAYANAN PUBLIK

DI MALL PELAYANAN PUBLIK KABUPATEN BANYUWANGI

\title{
INOVASI DALAM PELAYANAN PUBLIK DI MALL PELAYANAN PUBLIK KABUPATEN BANYUWANGI
}

\author{
Oleh: Putri Robiatul Adawiyah* \\ putri.ra@unmuhjember.ac.id \\ * Program Studi Ilmu Pemerintahan \\ Fakultas Ilmu Sosial dan Ilmu Politik Universitas Muhammadiyah Jember
}

Received: 10 Juli 2018, Revised: 19 Agustus 2018, Accepted: 23 Agustus 2018

\begin{abstract}
Abstrak
Penelitian ini dilakukan untuk mengetahui inovasi dan pelayanan apa saja yang ada di Mall Pelayanan Publik Banyuwangi, serta mengetahui bagaimana proses pelayanan publik terkait waktu, persyaratan, prosedur dan biaya. Mengetahui keunggulan dan inovasi dari Mall Pelayanan Publik, mencari perbedaan metode pelayanan satu atap dan satu pintu dengan pelayanan yang ada di Mall Pelayanan Publik Kabupaten Banyuwangi.

Kata Kunci: Inovasi, Mall Pelayanan Publik.
\end{abstract}

\begin{abstract}
This research was purposed to find out what innovations and services are available at Banyuwangi Public Service Mall, as well as how public service processes are related to time, requirements, procedures and costs. Knowing the advantages and innovations of the Public Service Mall, looking for one-stop and one-door service information with services available at Banyuwangi Regency Public Service Mall.

Keywords: Innovation, Public Service Mall.
\end{abstract}


Jurnal Politico Vol. 2 September 2018

Halaman 264-275. ISSN: p; 1829-6696, e:2549-4716

Web jurnal online; jurnal.unmuhjember.ac.id

Putri Robiatul Adawiyah

INOVASI DALAM PELAYANAN PUBLIK

DI MALL PELAYANAN PUBLIK KABUPATEN BANYUWANGI

\section{PENDAHULUAN}

\subsection{Latar Belakang}

Inovasi merupakan suatu hal penting yang harus dimiliki oleh sebuah organisasi pemberi layanan sektor publik. Instansi pemerintah sebagai pemberi layanan dituntut memiliki inovasi untuk meningkatkan kualitas pelayanan kepada masyarakat. Selama ini masih banyak permasalahan dalam kegiatan dan proses pemberian layanan kepada masyarakat. Beberapa pemerintah daerah berlombalomba bersaing dan berupaya memberikan pelayanan yang terbaik kepada masyarakat. Namun seringkali upaya tersebut masih belum memberikan hasil yang maksimal sehingga pada akhirnya tidak solutif dan terkadang menimbulkan kerumitan dalam proses pelayanan kepada masyarakat.

Kabupaten Banyuwangi melalui inovasinya dalam layanan publik meresmikan Mall Pelayanan Publik. Melalui kecepatan dan fasilitas pelayanan ini, menandakan komitmen pemerintah yang kuat dalam membangun daerah. Dengan mempelajari inovasi pemberi layanan di Kabupaten Banyuwangi, nantinya dapat ditemukan solusi dan inovasi yang dapat menjadi masukan bagi daerah lain untuk memperbaiki layanannya kepada masyarakat.

Sebagaimana kita ketahui, selama ini masih banyak kekurangan dari penyedia layanan publik sebagaimana yang dirumuskan dalam seminar evaluasi kualitas pelayanan publik dinyatakan bahwa terdapat beberapa permasalahan dalam pelayanan publik. Diantaranya masih sedikit instansi yang wajib memberikan layanan yang berstandar operasional prosedur, dan adanya kejelasan. Masih ada beberapa instansi penanggung jawab dan penyedia layanan yang masih belum mempunyai SOP berupa alur dan prosedur yang jelas dalam menyediakan pelayanan. Aspek durasi waktu pemberian layanan masih belum ada sehingga kurang efektif dan efisien serta dapat merugikan waktu masyarakat yang sedang mengakses pelayanan. Saat ini hanya beberapa penyedia layanan yang telah memiliki durasi waktu pemberian layanan seperti perpanjangan surat kendaraan yang sudah memiliki standar SOP dan durasi waktu pengurusan pelayanan. Dalam seminar tersebut juga diperoleh rumusan bahwa ketidakmampuan petugas pemberi layanan disebabkan karena kompetensi yang rendah serta kurang sesuai 
Jurnal Politico Vol. 2 September 2018

Halaman 264-275. ISSN: p; 1829-6696, e:2549-4716

Web jurnal online; jurnal.unmuhjember.ac.id

Putri Robiatul Adawiyah

INOVASI DALAM PELAYANAN PUBLIK

DI MALL PELAYANAN PUBLIK KABUPATEN BANYUWANGI

dengan pekerjaan untuk menyediakan pelayanan yang baik; Masih ada penyedia layanan yang bersikap kurang ramah, kurang sopan atau tidak jelas dalam berbicara, memberitahukan suatu informasi dengan tidak ramah/santun. Selain itu masih ada penyedia layanan masih belum menggunakan sarana prasarana yang layak serta sesuai kebutuhan konsumen, misalnya sarana khusus bagi difabel, ruang laktasi, antrian khusus bagi lansia, dan sistem konektivitas jaringan komputer, internet sehingga pada saat pengurusan layanan yang membutuhkan koneksi server pusat, layanan tidak dapat diberikan karena tidak ada koneksi jaringan.

Berdasarkan permasalahan tersebut, selanjutnya kami tertarik untuk mengadakan kegiatan kunjungan lapang serta melakukan kegiatan wawancara mendalam di Mall Pelayanan Publik Kabupaten Banyuwangi serta merumuskan beberapa permasalahan antara lain: mengidentifikasi pelayanan apa saja yang ada di Mall Pelayanan Publik Banyuwangi, mengetahui durasi waktu pelayanan dan proses pelayanan publik (waktu, persyaratan, prosedur dan biaya), mencari keunggulan dan inovasi dari Mall Pelayanan Publik, mencari perbedaan metode pelayanan satu atap dan satu pintu dengan pelayanan yang ada di Mall Pelayanan Publik Kabupaten Banyuwangi.

\subsection{Rumusan Masalah}

Adapun rumusan masalah penelitian ini yaitu: "Bagaimanakah Inovasi dalam Pelayanan Publik di Mall Pelayanan Publik Kabupaten Banyuwangi?

\subsection{Tujuan Penelitian}

Adapun tujuan penelitian ini untuk mengetahui bagaimanakah Inovasi dalam Pelayanan Publik di Mall Pelayanan Publik Kabupaten Banyuwangi.

\subsection{Manfaat Penelitian}

Adapun manfaat penelitian ini sebagai masukan kajian di bidang pelayanan publik, sebagai pengabdian dosen kepada msyarakat dan dapat digunakan sebagai dokumen pendukung kenaikan pangkat . 
Jurnal Politico Vol. 2 September 2018

Halaman 264-275. ISSN: p; 1829-6696, e:2549-4716

Web jurnal online; jurnal.unmuhjember.ac.id

Putri Robiatul Adawiyah

INOVASI DALAM PELAYANAN PUBLIK

DI MALL PELAYANAN PUBLIK KABUPATEN BANYUWANGI

\section{KAJIAN TEORI}

\subsection{Pengertian Inovasi}

Inovasi merupakan Proses memikirkan dan mengimplementasikan suatu gagasan yang memiliki unsur kebaruan dan kebermanfaatan (LAN, 2014).

Menurut Tri Widodo W. Utomo, inovasi bukan sekedar ada tidaknya kemanfaatan dari inisiasi perubahan dan kebaruan dalam proses perubahan. Namun di dalam inovasi harus mampu menginisiasi perubahan dan memberikan solusi pada permasalahan, serta memiliki kompatibilitas dengan sistem yang ada di luar dirinya, serta harus berkesinambungan dan dapat direplikasi (Tri Widodo W. Utomo, 2014).

\subsection{Pengertian Pelayanan Publik}

Pelayanan Publik merupakan seluruh bentuk layanan yang disediakan oleh pemerintah pusat atau daerah, BUMN/BUMD, untuk memenuhi kebutuhan masyarakat, dan atau perundang-undangan yang berlaku Kep Men Pan No. 81/93. Pelayanan publik merupakan suatu kegiatan atau suatu rangkaian kegiatan yang bertujuan memenuhi kebutuhan pelayanan berdasarkan peraturan perundangundangan bagi setiap warga negara dan penduduk atas barang, jasa, dan/atau layanan administratif oleh penyedia layanan publik. Penyelenggara layanan publik disebut penyelenggara yaitu setiap institusi penyelenggara negara, korporasi, lembaga independen yang dibentuk berdasarkan undang-undang dalam pelaksanaan kegiatan pelayanan publik, serta badan hukum lainnya yang dibentuk semata-mata dalam rangka kegiatan pelayanan publik. (UU 25/2009).

Tugas Pemerintah yang berkenaan dengan layanan umum yaitu menyediakan pelayanan untuk masyarakat, memudahkan masyarakat mengakses layanan, memberikan ijin masyarakat, membina serta membimbing masyarakat, mengawasi dan mengatur masyarakat, mengayomi dan melindungi masyarakat. Pelayanan umum yang baik adalah bentuk pelayanan oleh birokrasi yang mampu memberikan kepuasan kepada masyarakat. Adapun fungsi utama Pemerintah Daerah sesuai dengan UU Nomor 5 Tahun 1974 yaitu sebagai promotor 
Jurnal Politico Vol. 2 September 2018

Halaman 264-275. ISSN: p; 1829-6696, e:2549-4716

Web jurnal online; jurnal.unmuhjember.ac.id

Putri Robiatul Adawiyah

INOVASI DALAM PELAYANAN PUBLIK

DI MALL PELAYANAN PUBLIK KABUPATEN BANYUWANGI

pembangunan, selanjutnya sesuai dengan UU Nomor 22/1999 maupun UU Nomor 32/2004 telah berubah menjadi konsep "pelayan masyarakat".

\section{METODE PENELITIAN}

\subsection{Jenis Penelitian}

Jenis Penelitian ini adalah penelitian kualitatif dengan menggunakan pedoman wawancara. Selanjutnya sumber data dari informan yang ditunjuk melalui tahap proses klasifikasi dan reduksi data, lalu proses pengolahan data dan terakhir proses analisis data dan perumusan hasil penelitian dan kesimpulan.

\subsection{Lokasi Penelitian}

Adapun lokasi penelitian adalah Kantor Mall Pelayanan Publik Kabupaten Banyuwangi, dimana di Mall tersebut terdapat inovasi dalam pelayanan publik.

\subsection{Waktu Penelitian}

Adapun waktu penelitian untuk melaksanakan penelitian adalah 2 November 2017, yaitu bertepatan dengan kegiatan kunjungan lapang mahasiswa yang telah disiapkan beberapa pertanyaan dalam pedoman wawancara. Adapun observasi awal dilakukan pada saat survey lapangan, selanjutnya penentuan informan dari guide yang diberikan oleh Pemkab Banyuwangi yaitu Bapak Sugeng dan ibu Kris menjadi informan utama, dan selanjutnya petugas pemberi layanan sebagai informan pendukung dan para masyarakat yang datang sebagai konsumen.

\subsection{Sumber data/informan dan Teknik Pengumpulan Data}

Penentuan penentuan informan awal dari guide yang diberikan oleh Pemkab Banyuwangi yaitu Bapak Sugeng dan ibu Kris menjadi informan utama, informan selanjutnya yakni petugas pemberi layanan yang ada di kantor Mall Pelayanan Publik Banyuwangi dan para masyarakat yang diwawancarai dan datang meminta pelayanan sebagai konsumen. Adapun sumber dan teknik 
Jurnal Politico Vol. 2 September 2018

Halaman 264-275. ISSN: p; 1829-6696, e:2549-4716

Web jurnal online; jurnal.unmuhjember.ac.id

Putri Robiatul Adawiyah

INOVASI DALAM PELAYANAN PUBLIK

DI MALL PELAYANAN PUBLIK KABUPATEN BANYUWANGI

pengumpulan data adalah menggunakan pedoman wawancara dengan cara beberapa data yang diperoleh dari pertanyaan yang diajukan saat wawancara dengan menggunakan pedoman wawancara dikumpulkan. Selanjutnya sumber data dari informan yang ditunjuk melalui tahap proses klasifikasi dan reduksi data.

\subsection{Analisis Data}

Analisis data dilaksanakan melalui dari beberapa data yang diperoleh berdasar pertanyaan yang diajukan saat wawancara dengan menggunakan pedoman wawancara dikumpulkan. Selanjutnya sumber data dari informan yang ditunjuk melalui tahap proses klasifikasi dan reduksi data, lalu proses pengolahan data dan terakhir proses analisis data dan perumusan hasil penelitian dan kesimpulan.

\section{PELAKSANAAN KEGIATAN DAN PEMBAHASAN}

\subsection{Deskripsi Mall Pelayanan Publik}

Mall pelayanan publik merupakan inovasi dalam pelayanan publik yang dicetuskan oleh Bupati Banyuwangi Bapak H. Abdullah Azwar Anas M.Si. yang diresmikan di akhir tahun 2017, merupakan pelayanan satu atap yang didalamnya terdapat banyak pelayanan-pelayanan yang bisa diakses masyarakat Banyuwangi. Pada saat kami berkunjung di Mall pelayanan publik sudah mencapai 149 jenis layanan dalam Mall pelayanan publik ini, dan kedepannya ditargetkan akan sekitar 200 lebih produk layanan yang dapat dilayani di kantor Mall Pelayanan Publik.

Adapun pelayanan yang diberikan di Mall pelayanan publik ini sebanyak 149 layanan mulai dari administrasi kependudukan seperti akte kelahiran dan kematian, Kartu Tanda Penduduk, Kartu Keluarga, beragam jenis izin SIUP, pengurusan surat sertifikat tanah, IMB, BPJS Kesehatan, BPJS Ketenagakerjaan, pelayanan PDAM, pelayanan izin terkait kendaraan di SAMSAT seperti SIM, STNK, BPKB, hingga pembayaran retribusi daerah dan Pajak Bumi dan Bangunan. Terdapat pula layanan pencatatan pernikahan oleh Kementrian Agama 
Jurnal Politico Vol. 2 September 2018

Halaman 264-275. ISSN: p; 1829-6696, e:2549-4716

Web jurnal online; jurnal.unmuhjember.ac.id

Putri Robiatul Adawiyah

INOVASI DALAM PELAYANAN PUBLIK

DI MALL PELAYANAN PUBLIK KABUPATEN BANYUWANGI

dan disediakan pula area khusus untuk tempat prosesi ijab dan kabul di gedung

Mall Pelayanan Publik Banyuwangi. Hal ini menunjukkan bahwa pemerintah Kabupaten Banyuwangi telah berupaya maksimal untuk mewujudkan pelayanan sektor publik lebih baik. Dengan adanya mall pelayanan publik warga tidak perlu ke berbagai instansi untuk mengurus satu keperluan, semuanya cukup di kerjakan langsung di Mall Pelayanan Publik Banyuwangi. Harapan dan upaya yang dilakukan bertujuan agar masyarakat yang mengurus dokumen di pemerintahan bukan lagi sesuatu yang berbelit-belit, rumit, serta dapat membosankan.

\subsection{Inovasi Mall Pelayanan Publik}

Adapun inovasi pada kantor Mall pelayanan publik di Kabupaten Banyuwangi antara lain sebagai berikut:

a. Pelayanan satu gedung yang dapat mempermudah proses pelayanan kepada masyarakat. Denah dan desain penataan lokasi ruang pelayanan Mall pelayanan publik yang sangat simple dan mudah dipahami oleh masyarakat awam sekalipun, sehingga hanya dalam satu tempat dan satu gedung, masyarakat bisa mengakses pelayanan dan berbagai macam produk layanan.

b. Berbagai macam produk layanan yang disediakan di Mall pelayanan publik. Selama ini, pelayanan satu atap hanya menyediakan satu macam produk layanan atau beberapa yang sejenis dalam satu intstansi saja. Namun di Mall pelayanan publik terdapat beberapa instansi penyedia layanan yang berada dalam satu gedung, sehingga produk layanan yang diberikan sangat banyak sesuai dengan kebutuhan masyarakat.

c. Data utama tersimpan dalam bank data sehingga tidak perlu entri ulang data, tinggal menambah data pendukung lainnya, bilamana melakukan permohonan layanan lainnya.

d. Proses pelayanannya cepat dan selesai dalam waktu tertentu. Untuk pelayanan yang sederhana serta persyaratan sudah dilengkapi oleh konsumen pengguna layanan, maka petugas dapat memberikan pelayanan 1 hari selesai. 
Jurnal Politico Vol. 2 September 2018

Halaman 264-275. ISSN: p; 1829-6696, e:2549-4716

Web jurnal online; jurnal.unmuhjember.ac.id

Putri Robiatul Adawiyah

INOVASI DALAM PELAYANAN PUBLIK

DI MALL PELAYANAN PUBLIK KABUPATEN BANYUWANGI

e. Mempermudah masyarakat dalam melakukan proses pelayanan.

Masyarakat mudah mengakses layanan, tidak perlu ke berbagai lokasi kantor yang berbeda, cukup ke satu lokasi saja. Proses pelayanan juga sederhana.

f. Lebih efisien waktu dan biaya dalam proses pelayanan. Dengan adanya lokasi yang berada di satu gedung, maka waktu yang diperlukan oleh masyarakat juga efisien. Biaya yang dikeluarkan oleh pemerintah dalam proses pelayanan administrasi juga efisien. Menurut sumber informan saat ini biaya penyelenggaraan pelayanan di Mall Pelayanan Publik masih menggunakan biaya dari SKPD masing-masing yang mendukung dan berkontribusi dalam pemberian layanan. Kedepannya pemerintah Kabupaten Banyuwangi akan menyediakan anggaran khusus untuk biaya proses penyelenggaraan pelayanan di Mall Pelayanan Publik Kabupaten Banyuwangi.

g. Terpampang jelas alur dan SOP layanan. Ketika memasuki areal Mall Pelayanan Publik, sudah terpampang masing-masing alur dan SOP pada tiap-tiap produk layanan. Masyarakat awampun akan mudah memahami karena persyaratan yang dibutuhkan untuk pengurusan layanan sudah tertulis jelas. Bila memang ada hal yang kurang dipahami, maka masyarakat dapat menanyakan langsung di bagian informasi.

h. Disediakan juga ruang kesehatan dan menyusui bagi masyarakat yang sedang menunggu layanan di kantor Mall Pelayanan Publik sehingga masyarakat tidak bosan dan jenuh menunggu antrian pelayanan.

i. Lokasi gedung Mall Pelayanan Publik yang sangat strategis berada di areal Taman Sritanjung dan Masjid Jami', serta memiliki ruang tunggu dan lahan parkir yang cukup luas. Untuk masyarakat difabel juga terdapat sarana khusus yang disediakan.

j. Terdapat ruang bermain bagi anak-anak yang disediakan bagi konsumen yang membawa anak pada saat mengurusi pelayanan.

k. Terdapat ruang pojok baca bagi masyarakat yang jenuh menunggu antrian pelayanan. 
Jurnal Politico Vol. 2 September 2018

Halaman 264-275. ISSN: p; 1829-6696, e:2549-4716

Web jurnal online; jurnal.unmuhjember.ac.id

Putri Robiatul Adawiyah

INOVASI DALAM PELAYANAN PUBLIK

DI MALL PELAYANAN PUBLIK KABUPATEN BANYUWANGI

Adapun keunggulan pada kantor Mall pelayanan publik di Kabupaten

Banyuwangi antara lain sebagai berikut:

a. Penyelenggaraan pelayanan pada Mall pelayanan publik di Kabupaten Banyuwangi mendapat dukungan penuh dari seluruh instansi dan SKPD yang ada di Banyuwangi. Sehingga adanya itikad dari semua pihak yang mendukung terwujudnya inovasi dalam pelayanan publik.

b. Adanya respon positif dari masyarakat yang partisipatif dan masyarakat yang kritis akan kesadaran atas Hak-haknya.

c. Adanya transparansi dan akuntabilitas dalam pelayanan publik, sehingga semua pihak dapat memantau dan membantu pembangunan dan perkembangan Mall pelayanan publik. Apa sajakah yang dibutuhkan oleh Mall pelayanan publik, apa saja yang bisa diberikan untuk menyempurnakan layanan di Mall pelayanan publik.

d. Adanya teknologi yang mendukung dalam proses penyediaan layanan di Mall pelayanan publik.

e. Adanya Undang-undang yang mendukung proses pembangunan Mall Pelayanan Publik Banyuwangi.

f. Adanya anggaran yang didukung dari berbagai pihak mendukung proses pembangunan Mall Pelayanan Publik Banyuwangi.

g. Pelayanan satu gedung yang dapat mempermudah proses pelayanan kepada masyarakat. Denah dan desain penataan lokasi ruang pelayanan Mall pelayanan publik yang sangat simple dan mudah dipahami oleh masyarakat awam sekalipun, sehingga hanya dalam satu tempat dan satu gedung, masyarakat bisa mengakses pelayanan dan berbagai macam produk layanan.

h. Terdapat perbedaan metode pelayanan satu atap dan satu pintu dengan mall pelayanan publik yang ada di Banyuwangi terletak pada variasi ragam produk yang disajikan bermacam-macam. Pada pelayanan satu atap dan satu pintu, produk layanan yang diberikan hanya satu jenis saja dari satu instansi. Selain itu proses pelayanan dan juga alat yang digunakan, didalam metode konvensional atau klasik alat yang digunakan cenderung 
Jurnal Politico Vol. 2 September 2018

Halaman 264-275. ISSN: p; 1829-6696, e:2549-4716

Web jurnal online; jurnal.unmuhjember.ac.id

Putri Robiatul Adawiyah

INOVASI DALAM PELAYANAN PUBLIK

DI MALL PELAYANAN PUBLIK KABUPATEN BANYUWANGI

masih tidak kompatibel sehingga proses pelayanannya membutuhkan waktu yang lebih lama dari apa yang dijanjikan dan diharapkan sehingga dapat memperlambat proses pelayanan yang telah diproses namun jauh berbeda pada saat akan melakukan proses pelayanan di mall pelayanan publik dilihat dari segi alat dan juga proses pelayanannya sudah cenderung dilakukan dengan cara modern baik alat yang sudah digunakan sehingga mempercepat proses pelayanan yang ada di mall pelayanan publik yang efisien waktu dan biaya.

\section{KESIMPULAN}

Dari hasil penelitian diperoleh kesimpulan bahwa melalui Mall Pelayanan Publik di Kabupaten Banyuwangi, bahwa Pemerintah Kabupaten Banyuwangi telah berupaya mewujudkan inovasi dalam pelayanan publik sehingga masyarakat dapat mengakses dengan mudah segala layanan administratif secara lebih efektif dan efisien. Adapun proses pelaksanaan dan pembangunan Mall Pelayanan Publik mendapat dukungan sepenuhnya dari berbagai pihak, baik dari SKPD- SKPD dan instansi-instansi penyedia layanan, maupun dukungan penuh dari masyarakat Banyuwangi. 
Jurnal Politico Vol. 2 September 2018

Halaman 264-275. ISSN: p; 1829-6696, e:2549-4716

Web jurnal online; jurnal.unmuhjember.ac.id

Putri Robiatul Adawiyah

INOVASI DALAM PELAYANAN PUBLIK

DI MALL PELAYANAN PUBLIK KABUPATEN BANYUWANGI

\section{DAFTAR PUSTAKA}

Bagir Manan, Hubungan Antara Pusat dan Daerah Menurut UUD 1945, Armico, Bandung, 1995

Kamus Besar Bahasa Indonesia, 2008

Sugiyono. 2009. Metode Penelitian Kuantitatif Kualitatif dan R\&D. Bandung:

Alfabeta.

Tri Widodo W. Utomo, Inovasi Pelayanan Publik, 2014

Lembaga Administrasi Negara, 2014

Modul Tata Kelola Pelayanan Publik Berbasis Standar, USAID-KINERJA, Jakarta, 2014

Peraturan Menteri Negara Pendayagunaan Aparatur Negara dan Reformasi Birokrasi Nomer 13 Tahun 2009 tentang Pedoman Peningkatan Kualitas Pelayanan Publik dengan Partisipasi Masyarakat

Peraturan Menteri Negara Pendayagunaan Aparatur Negara dan Reformasi Birokrasi Nomor 38 Tahun 2012 tentang Pedoman Penilaian Kinerja Unit Pelayanan Publik

Undang-Undang Republik Indonesia Nomor 25 Tahun 2009 tentang Pelayanan Publik

Undang-Undang Republik Indonesia Nomer 5 Tahun 2014 tentang Aparatur Sipil Negara. 